\title{
En mann i 30-årene med ulcerøs kolitt og pancytopeni
}

\author{
En mann i 30-årene ble innlagt i sykehus med mistanke om forverring \\ av ulcerøs kolitt. En tverrfaglig utredning avdekket en potensielt livs- \\ truende tilstand.
}

En mann med mangeårig ulcerøs kolitt ble innlagt $i$ gastromedisinsk avdeling som øyeblikkelig hjelp på grunn av redusert allmenntilstand og hyppige tømminger. Pasienten hadde kjent bipolar lidelse som ble behandlet med olanzapin. Behandlingen av hans ulcerøse kolitt hadde vært komplisert grunnet prednisolonrelatert depresjon og infusjonsreaksjon på infliximab, men pasienten hadde det siste året vært i remisjon, med en kombinasjonsbehandling av mesalazin $2,4 \mathrm{~g} \times 2$ og azatioprin $150 \mathrm{mg} \times 1$.

Ved innleggelsen var mannen $i$ god allmenntilstand. Han beskrev milde gastrointestinale symptomer $i$ form av episoder med kvalme og oppkast, i tillegg til flere løse tømminger daglig uten synlig blod eller slim. Han anga ingen abdominalsmerter, rektale tenesmer, nattlig diaré eller vekttap. Derimot beskrev han betydelig nattesvette og periodisk feberfølelse den siste uken før innleggelsen. Han var febril med temperatur på $39,1^{\circ} \mathrm{C}$, og takykard, med puls på 116 slag/min. Ved klinisk undersøkelse var det upåfallende somatisk status, inkludert lymfestasjoner. Han var bløt $i$ abdomen ved palpasjon og anga ingen slippømhet. Biokjemisk forelå lettgradig pancytopeni, med $\mathrm{Hb}$ $12,2 \mathrm{~g} / \mathrm{dl}(13,4-17,0 \mathrm{~g} / \mathrm{dl}$ ), leukocytter 1,2 $\times$ $10^{9} / \mathrm{l}\left(3,5-8,8 \times 10^{9} / \mathrm{l}\right)$, nøytrofile $0,9 \times 10^{9} / \mathrm{l}$ $\left(1,7-8,2 \times 10^{9} / \mathrm{l}\right)$ og trombocytter $118 \times 10^{9} / \mathrm{l}$ (145-348 $\times 10^{9} /$ l). I tillegg hadde pasienten CRP på $68 \mathrm{mg} / \mathrm{l}(<7 \mathrm{mg} / \mathrm{ll}$, samt forhøyet ALAT-verdi på $173 \mathrm{U} / \mathrm{l}$ (10-70 U/l) (tab 1). $\emptyset$ vrige lever- og nyreverdier var normale. Røntgen thorax var normal. Det ble tatt blodkulturer, urin- og avføringsprøver, inkludert mikrobiologiprøver, i tillegg til fekal kalprotektin.

Pasientens gastrointestinale symptomer ble oppfattet som forverring av ulcerøs kolitt med bakteriell superinfeksjon. Mottakende lege valgte å starte med bredspektret antibiotikum i form av intravenøs piperacillin/ tazobactam, $4 \mathrm{~g} \times 3$. Blodprøveverdiene ga mistanke om hepatitt og beinmargssuppresjon. Det forelå i tillegg kliniske B-symptomer i form av feber og nattesvette. Dette indikerte en mer sammensatt tilstand med uklar sammenheng mellom funnene og hans kroniske inflammatoriske tarmsykdom.
Det forelå ingen relevant reiseanamnese eller kjent eksponering for tuberkulose, malaria eller myelotoksiske stoffer utover hans faste medikamenter. Pasienten benektet alkoholmisbruk. Anamnestisk forelå det ingen risikofaktorer for endokarditt. Ved undersøkelse fant man heller ingen endokardittstigmata, som hjertebilyd eller nevrologiske utfall, splinterblødninger, Roths flekker, Janeways lesjoner eller Oslers knuter.

I løpet av natten fikk pasienten febertopper opp mot $39,5^{\circ} \mathrm{C}$. Han hadde i tillegg flere episoder med oppkast, men kun en løs tarmtømming. Blodtrykk, puls og saturasjon var normale. Ved visitt første dag etter innleggelsen var han sirkulatorisk og respiratorisk stabil, tørr og varm i huden. I tillegg til uendret pancytopeni var det tilkommet økning i leverprøvene, med ALAT $569 \mathrm{U} / \mathrm{l}$ (10-70 U/(), ALP $149 \mathrm{U} / \mathrm{l}$ (35-105 U/l), GGT $199 \mathrm{U} / \mathrm{l}$ (10-80 U/l), bilirubin $9 \mu \mathrm{mol} / \mathrm{l}(5-25)$. Det forelå også lettgradig leversynteseaffeksjon, med lettgradig hypoalbuminemi på $28,7 \mathrm{~g} / \mathrm{l}(36-48 \mathrm{~g} / \mathrm{l})$ og spontan INR-verdi på 1,3 (0,9-1,2). CRP-nivået var $77 \mathrm{mg} / \mathrm{l}$ (tab 1).

Forhøyet ALAT-verdi, normalt bilirubinnivå og beskjedent forhøyede staseparametere kunne være forenlig med viral hepatitt og med immunologisk leversykdom, som autoimmun hepatitt. Antistoffer mot glatt muskulatur og mitokondrier var negative, og nivåene av immunglobuliner (IgA, IgM og IgG) var alle normale, noe som talte mot autoimmun hepatitt og primær biliær cirrhose. Primær biliær cirrhose og primær skleroserende kolangitt ble vurdert som lite sannsynlig fordi leverprøvene tidligere alltid hadde vært normale, og det nå hadde tilkommet rask og betydelig stigning. Ved gjentatt alkoholanamnese fremkom ikke opplysninger om høyt alkoholinntak. Dette, kombinert med ASAT/ALAT-ratio på mindre enn én, svekket mistanken om alkoholrelatert leverskade.

Både azatioprin og olanzapin kan gi pancytopeni og hepatitt. Man valgte i første omgang å seponere azatioprin første innleggelsesdag. Olanzapin ble kontinuert for å unngå en forverring av pasientens bipolare lidelse. Begge bivirkninger er også beskrevet for mesalazin, men man vurderte det som mindre sannsynlig at dette medikamen-

\section{Jens Vikse}

jensvikse@gmail.com

Jagiellonian University

Krakow

Daniel Limi Cacic

Avdeling for blod og kreftsykdommer

Arne Carlsen

Gastroenterologisk seksjon

Medisinsk divisjon

Trond Johan Cooper

Infeksjonsmedisinsk seksjon

Medisinsk divisjon

Tore Grimstad

Gastroenterologisk seksjon

Medisinsk divisjon

Stavanger universitetssjukehus

Engelsk oversettelse på www.tidsskriftet.no 
Tabell 1 Pasientens blodprøvesvar under innleggelsen

\begin{tabular}{|c|c|c|c|c|c|c|c|}
\hline & Innkomst & Dag 2 & Dag 3 & Dag 5 & Dag 8 & Dag 11 & Dag 18 \\
\hline Hemoglobin $(13,7-17,0 \mathrm{~g} / \mathrm{dl})$ & 12,2 & 11,6 & 11,0 & 10,5 & 11,8 & & 11,5 \\
\hline Leukocytter $\left(3,5-8,8 \times 10^{9} / 1\right)$ & 1,2 & 1,8 & 1,6 & 1,9 & 2,5 & & 5,0 \\
\hline Nøytrofile $\left(1,7-8,2 \times 10^{9} / l\right)$ & 0,9 & 1,0 & 0,8 & 0,7 & 0,8 & & 0,7 \\
\hline Trombocytter (145-348 × 109/l) & 118 & & & 86 & 118 & & 266 \\
\hline $\operatorname{INR}(0,9-1,2)$ & & 1,3 & 1,2 & 1,2 & & & \\
\hline Ferritin $(17-428 \mu \mathrm{g} / \mathrm{l})$ & & & 13308 & 10063 & 4944 & & 1458 \\
\hline ALAT (10-17 U/l) & 173 & 569 & 554 & 586 & 283 & & 147 \\
\hline $\mathrm{CRP}(<7 \mathrm{mg} / \mathrm{l})$ & 68 & 77 & 74 & 38 & 26 & & \\
\hline CMV $(<50 \mathrm{mg} / \mathrm{kg})$ & & & & 4600 & 7840 & 17000 & 435 \\
\hline Kalprotektin & & 58 & & & & & \\
\hline
\end{tabular}

tet forårsaket pasientens blodprøvefunn. På bakgrunn av hans ulcerøse kolitt og uavklarte infeksjonssymptomer ble det tatt CT av abdomen med kontrast for å utelukke intraabdominalt infeksjonsfokus, toksisk megacolon og eventuell abscedering. Denne undersøkelsen viste normale forhold i GItraktus, lever og galleganger.

Det var ikke holdepunkter for betydelig kolittaktivitet: Fekal kalprotektin dag 2 var $58 \mathrm{mg} / \mathrm{kg}(<50 \mathrm{mg} / \mathrm{kg})$, og bakterieundersøkelser av feces var negative. Behandlende gastroenterolog valgte å avvente koloskopi på bakgrunn av leukopeni og risiko for infeksiøse komplikasjoner. Infeksiøs eller hematologisk etiologi ble nå vurdert som mest nærliggende.

Virusinfeksjoner representerer viktige differensialdiagnoser ved akutt hepatitt og beinmargssuppresjon hos immunsupprimerte pasienter. Pasienten hadde ingen relevant seksual- eller rusanamnese som pekte i retning risiko for virushepatitt eller hiv. Rutinemessig ble det rekvirert prøver for hepatitt A, B og C (HAV, HBV, HCV), samt cytomegalo-, Epstein-Barr-, varicella zoster-virus (CMV, EBV, VZV), parvovirus B19 og humant immunsviktvirus (hiv).

Tredje innleggelsesdag ble allmenntilstanden forverret, og gjennom natten ble det registrert svingende temperatur $36-39,5^{\circ} \mathrm{C}$. CRP holdt seg fortsatt uendret omkring 70 $\mathrm{mg} / \mathrm{l}$. Det forelå prøvesvar for blodkulturer, urinprøve, avføringsprøver og legionella samt pneumokokkantigen i urin, som alle var negative. Pasienten ble vurdert i samråd med infeksjonsmedisiner, og som et ledd $i$ ytterligere utredning ble ferritin rekvirert.

Pasienten var blitt behandlet med intravenøs piperacillin/tazobactam $\mathrm{i}$ to døgn, uten åpen- bar klinisk eller biokjemisk respons. Hos pasienter med pancytopeni og akutt hepatitt må også hematologiske og revmatologiske tilstander overveies. Blodutstryk, beinmargsaspirasjon og lymfeknutebiopsi står sentralt ved mistanke om akutt leukemi eller lymfom. Pasienten hadde ingen palpabel lymfeknutesvulst, og supplerende CT av collum var uten patologiske funn. Pasienten anga ikke kjent forekomst av bindevevssykdommer eller autoimmune sykdommer i slekten. Prøver for antinukleære antistoffer (ANA), anti-Sm og anti-ds-DNA var innenfor referanseområdet. Perifert blodutstryk viste få leukocytter og blodplater, men ingen blaster.

Påfølgende natt ble pasienten takykard og takypnoeisk, med systolisk blodtrykksfall fra 130 til $100 \mathrm{~mm} \mathrm{Hg}$. På grunn av økende dyspné og hypoksi (SaO2 89-90\%) fikk han oksygen på nesekateter. Ved auskultasjon var det normale lungefysikalia. Han ble kortvarig observert på intensivmedisinsk overvåkning, men ble flyttet tilbake til sengepost samme dag. Blodprøver viste betydelig forhøyet serum ferritin, $13308 \mu \mathrm{g} / \mathrm{l}(17-428 \mu \mathrm{g} / \mathrm{l})$.

Symptomene kunne tenkes relatert til lungeemboli, som pasienter med ulcerøs kolitt er disponert for (1). Pasientens dyspné og surstoffmetning bedret seg etter kort tid uten ytterligere behandling, og dette ble ikke utredet nærmere.

En sjelden, men alvorlig, differensialdiagnose ved febril pancytopeni hos immunsupprimerte pasienter er hemofagocytisk lymfohistiocytose (HLH). Diagnostiske kriterier er anført i ramme 1.

På mistanke om utvikling av sekundær hemofagocytisk lymfohistiocytose ble det gjennomført beinmargsaspirasjon. I tillegg ble triglyserider og serum-fibrinogen analysert, disse var innenfor referanseområdene. En regranskning av pasientens CT abdomen avdekket lettgradig splenomegali $113 \mathrm{~cm}$ i lengdesnitt). Beinmargsaspirat viste enkelte stromale makrofager med fagocytterte erytrocytter (fig 1 og 2). Kvantitativ PCR viste cytomegaloviremi, med 4600 kopier CMV per milliliter. CMV-serologi påviste IgM- og IgG-antistoff, hvor titermåling viste høy IgM og lav IgG, forenelig med aktuell CMV-infeksjon. Øvrige virusprøver var negative.

Pasienten hadde ulcerøs kolitt under immunsupprimerende behandling med azatioprin. Han pådro seg en interkurrent cytomegalo-

\section{RAMME 1}

Diagnostiske kriterier for hemofagocytisk lymfohistiocytose (22) (Diagnose:

$\geq 5$ kriterier)

1. Feber $\geq 38,5^{\circ} \mathrm{C}$

2. Splenomegali

3. Cytopeni med minst to av de følgende:

a) $\mathrm{Hb}<9 \mathrm{~g} / \mathrm{dl}$

b) Trombocytter $<100 \times 10^{9} / \mathrm{l}$

c) Absolutt nøytrofiltall $<1,0 \times 109 / \mathrm{l}$

4. Enten:

a) Hypertriglyceridemi (fastende triglycerider $\geq 3,0 \mathrm{mmol} / \mathrm{l}$ ) eller

b) Hypofibrinogenemi (fibrinogen $\leq 1,5 \mathrm{~g} / \mathrm{l}$ )

5. Hemofagocytose i enten benmarg, milt, lever eller lymfeknute

6. Lav eller fraværende NK-celleaktivitet

7. Ferritin $>500 \mu \mathrm{g} / \mathrm{l}$

8. Løselig CD25 (IL2-reseptor alfa) $\geq 2400$ $\mathrm{U} / \mathrm{ml}$ 


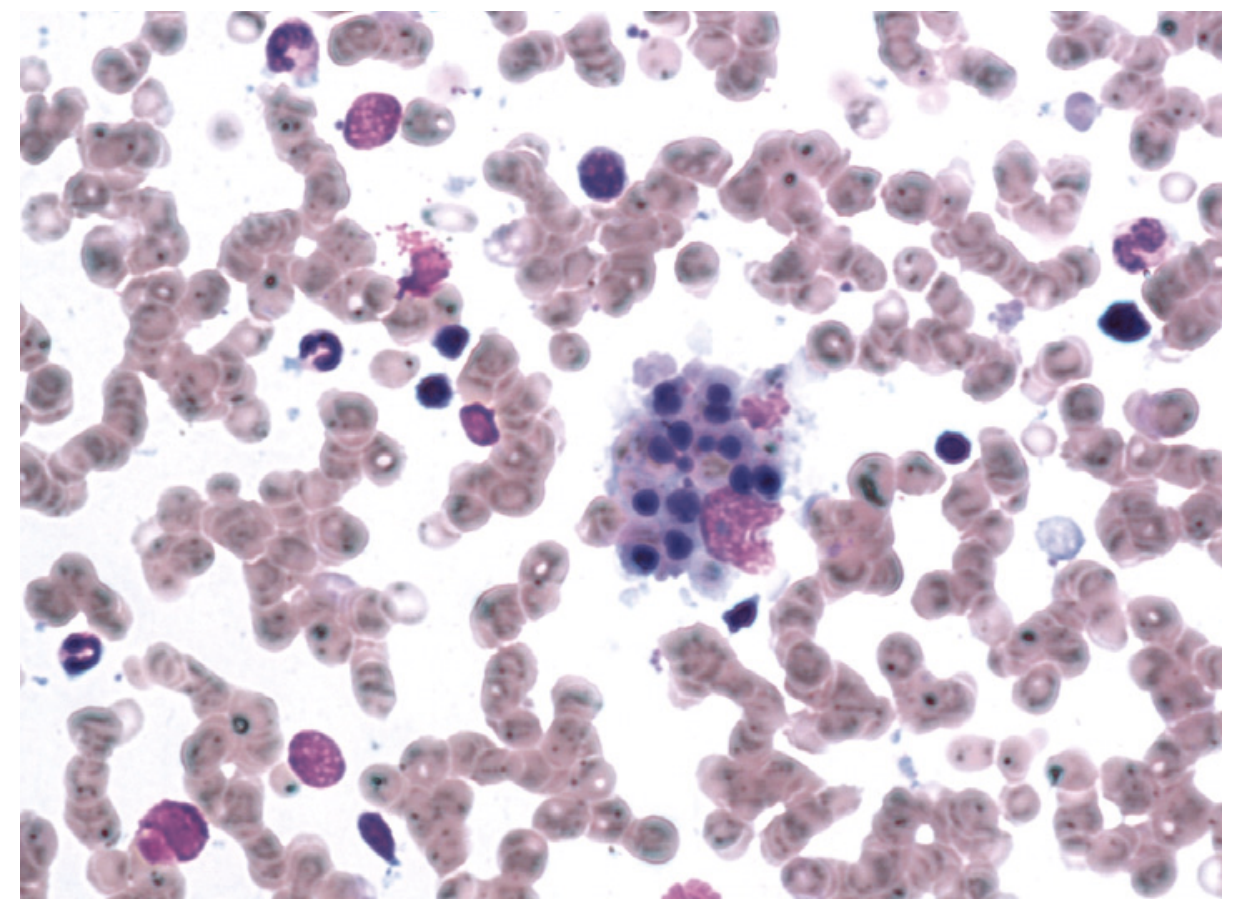

Figur 1 Bilde av pasientens beinmargsaspirat med enkelte stromale makrofager med fagocytterte erytrocytter. I cytoplasma ses både mørke legemer/kjerner som vurderes som erytroide forstadier og lysere erytrocytter (samme farge som erytrocyttene i bakgrunnen)

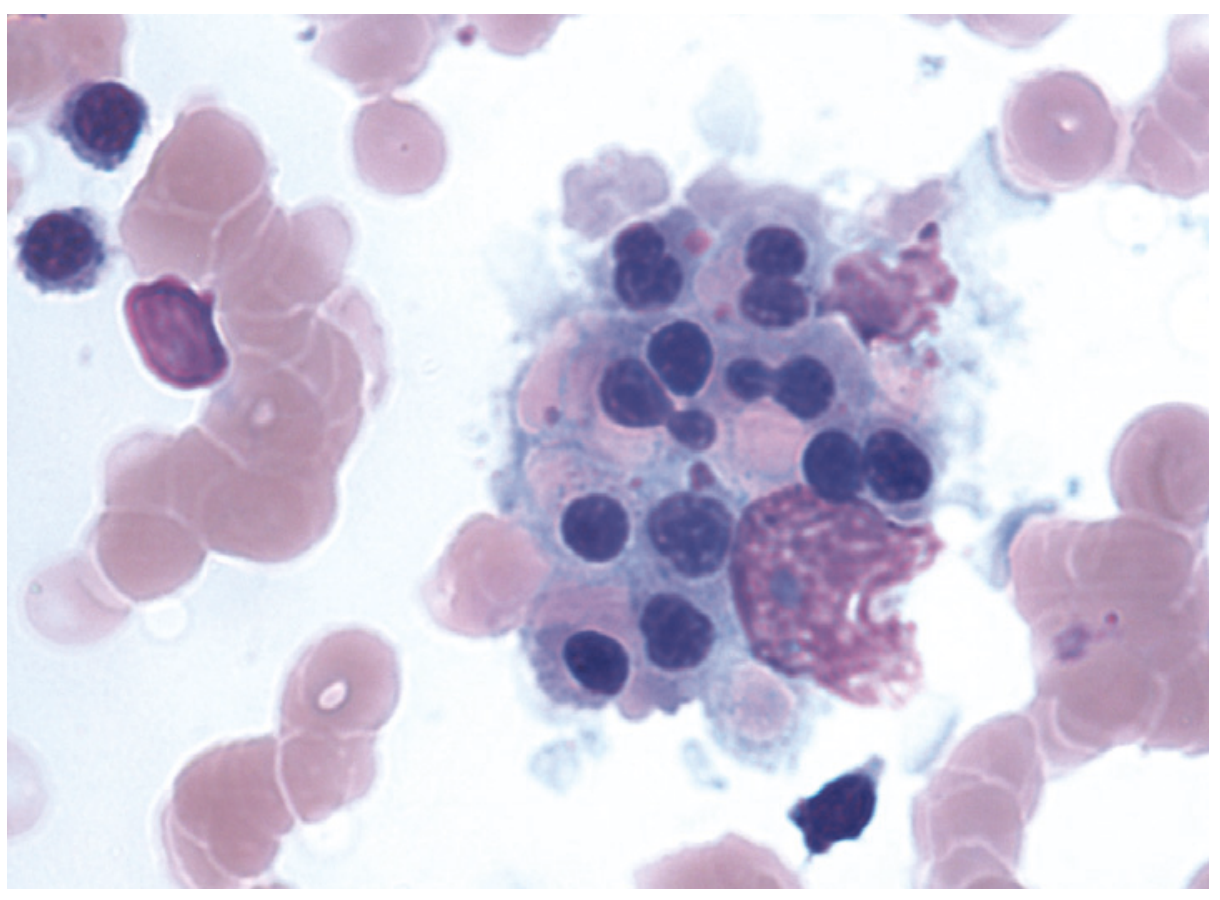

Figur 2 Forstørret utsnitt av figur 1 av pasientens beinmargsaspirat virusinfeksjon og utviklet sannsynligvis sekundær hemofagocytisk lymfohistiocytose.

Etter fem dager i medisinsk avdeling ble pasienten overflyttet til avdeling for blod-og kreftsykdommer for videre behandling og observasjon. Grunnet stabil klinisk tilstand og påvist utløsende årsak til hemofagocytisk lymfohistiocytose ble pasienten først observert ubehandlet. Antibiotika ble seponert syvende dag etter innleggelsen. Ved CMVPCR-kontrollprøve ble det påvist økende viremi, med 7800 kopier per milliliter, og som målrettet behandling for hans CMVinfeksjon det ble igangsatt intravenøs antiviral terapi med ganciklovir $350 \mathrm{mg} \times 2$ i syv dager med overgang til peroral valganciklovir $900 \mathrm{mg} \times 2$ i syv dager ved utskrivelse.

Ved utskrivelse etter et sykehusopphold på 19 dager var pasienten stabil og klinisk kjekk. Blodprøveverdiene var nesten normalisert.

\section{Diskusjon}

Ulcerøs kolitt er en inflammatorisk tarmsykdom som affiserer tykktarm i variabel utstrekning, med en insidens på 14 tilfeller per 100000 (2). Basisbehandlingen er 5aminosalisylsyrepreparater som mesalazin. Mange har i tillegg behov for kortikosteroider i perioder med moderat til alvorlig sykdomsaktivitet.

Pasienten ble innlagt med mistanke om økende sykdomsaktivitet av sin ulcerøse kolitt. Ved økende sykdomsaktivitet forekommer vanligvis hyppige tarmtømminger. Avføringen kan også være blodtilblandet. Kolitt med feber indikerer betydelig sykdomsaktivitet. Hos den aktuelle pasienten var det ved innleggelsen mistanke om aktiv kolitt med bakteriell superinfeksjon. Bakteriell superinfeksjon ble ikke bekreftet ved fecesdyrking, og fekal kalprotektin var tilnærmet normal, noe som indikerte normal slimhinne i tykktarmen. Det forelå derfor ikke holdepunkter for å mistenke aktiv ulcerøs kolitt. Det var rimelig å anta at hans febrile pancytopeni og hepatitt skyldtes kompliserende tilstander som ikke var direkte knyttet til aktiv kolitt.

Behandling med aminosalisylater er hjørnesteinen i behandlingen av ulcerøs kolitt. Bivirkningsprofilen til aminosalisylatene er gunstig, men siden det er beskrevet sjeldne tilfeller av pancytopeni og hepatitt (3) kunne dette medikamentet også med fordel blitt seponert hos vår pasient. Immunsupprimerende behandling med tiopuriner $\mathrm{i}$ form av peroral azatioprin eller 6-merkaptopurin blir ofte anvendt som ledd i langtidsbehandling dersom pasienten ikke responderer på basismedikasjon med aminosalisylater, eller behøver vedvarende/repetert steroidbehandling for å opprettholde remisjon (4).

Azatioprin er et prodrug som omdannes i 
leveren til 6-merkaptopurin, og via flere metabolske trinn til den biologiske aktive metabolitten 6-tioguaninnukleotid (6-TGN). Purinsyntesen hemmes, og prolifererasjon av T- og B-lymfocytter blir forhindret (5). Medikamentet har en variabel metabolisme og kan medføre en rekke bivirkninger, hvorav kvalme, oppkast, slapphet, utslett, feber og leddsmerter forekommer hyppig. Opptil $20-25 \%$ av pasientene avslutter behandlingen grunnet intoleranse (6). Mer alvorlige, men sjeldne, bivirkninger inkluderer pankreatitt, hepatitt, nyresvikt og beinmargssuppresjon. Det er dokumentert en viss fare for ikke-melanom hudkreft, lymfomutvikling, inkludert hepatosplenisk T-cellelymfom, særlig hos menn under 40 år (7). Ved oppstart av behandlingen tilrådes ukentlig blodprøvekontroll de første 3-4 uker, og deretter om lag hver tredje måned så lenge medikamentet benyttes. I tillegg tilrådes jevnlige 6-TGNserumspeilmålinger (5).

Hos vår pasient kunne både feber, pancytopeni og hepatitt forklares av azatioprinbruk, og dette kan oppstå både tidlig (dager-måneder) eller sent (måneder-år) etter behandlingsstart (6). Medikamentet ble derfor seponert ved innkomst. Olanzapin er et antipsykotikum som kan gi pancytopeni (8), og det kan muligens også være hepatotoksisk (9). Man valgte å ikke seponere olanzapin på grunn av antatt risiko for forverring av pasientens bipolare lidelse.

Fjerde innleggelsesdøgn ble det påvist betydelig hyperferritinemi. Selv om dette isolert sett kan skyldes hepatocellulær skade, hemokromatose, nyresvikt eller hematologisk malignitet, ledet dette, sammen med febril pancytopeni, mistanken mot hemofagocytisk lymfohistiocytose. Tilstanden er tidligere beskrevet utfyllende i Tidsskriftet (10). Ferritin over $10000 \mu \mathrm{g} / 1$ angis i en rapport å være $90 \%$ sensitivt og $98 \%$ spesifikt for hemofagocytisk lymfohistiocytose i pediatriske pasienter (11), mens man $i$ en annen studie fant begrenset diagnostisk verdi blant voksne pasienter (12). Diagnosen hemofagocytisk lymfohistiocytose stilles på bakgrunn av diagnostiske kriterier (ramme 1), hvor minst fem av åtte kriterier må foreligge for å sannsynliggjøre tilstanden. Pasienten i denne kasuistikken oppfylte fem kriterier - feber, splenomegali, pancytopeni, hyperferritinemi og hemofagocytter i beinmargsaspirat.

Hemofagocytisk lymfohistiocytose er en potensielt livstruende tilstand som oppstår hos om lag 1 av 1000000 personer årlig, og er forårsaket av dysfunksjonell immunhomeostase, som medfører vedvarende hyperaktivering av makrofager $(13,14)$. Makrofager skiller ut store mengder cytokiner, som kan forklare de kliniske og biokjemiske manifestasjonene ved hemofagocy- tisk lymfohistiocytose. Tilstanden kan være genetisk betinget (primær hemofagocytisk lymfohistiocytose), eller oppstå sekundært til autoimmun sykdom, immunsuppresjon, malignitet eller infeksjon (sekundær hemofagocytisk lymfohistiocytose) (15).

Hos vår pasient ble det påvist en systemisk CMV-infeksjon, som ut fra serologimønsteret kan ha vært en primærinfeksjon. Nyere litteratur angir at behandling av utløsende årsak til antatt sekundær hemofagocytisk lymfohistiocytose er av kritisk betydning (13). Oppstart av hemofagocytisk lymfohistiocytose-rettet behandling er kun indisert for de av pasientene som opplever suboptimal effekt og/eller forverring under behandling av utløsende årsak. I tråd med dette valgte man å behandle hans CMVinfeksjon som var antatt utløsende faktor for hemofagocytisk lymfohistiocytose. Spesifikk behandling av hemofagocytisk lymfohistiocytose med etoposid og deksametason ble vurdert fortløpende.

Hos pasienter med inflammatorisk tarmsykdom er det i litteraturen beskrevet fatale tilfeller av hemofagocytisk lymfohistiocytose under azatioprinbehandling, hvor det tilkommer interkurrent EBV-infeksjon (16). Lignende alvorlige forløp med hemofagocytisk lymfohistiocytose er beskrevet med CMV-viremi som utløsende faktor, selv om tarmsykdommen var i remisjon under azatioprinbehandlingen (17). Dette passer godt med sykehistorien i vår kasuistikk.

Man antar at kombinasjonen av kronisk inflammasjon og immunsuppresjon, primært form av tiopuriner, men også kombinasjon av tiopuriner og biologiske legemidler eller steroider, kan disponere for utvikling av hemofagocytisk lymfohistiocytose $(18,19)$. I forbindelse med akutt virusinfeksjon, som cytomegalovirus eller Epstein-Barr-virus, kan azatioprin bidra til å utløse sekundær hemofagocytisk lymfohistiocytose hos pasienter med inflammatorisk tarmsykdom. Selv om tilstanden er sjelden, er sekundær hemofagocytisk lymfohistiocytose ved inflammatorisk tarmsykdom en alvorlig tilstand med høy mortalitet, angitt til 30\% (20).

Hemofagocytisk lymfohistiocytose er omtalt i retningslinjene til den europeiske Crohns- og kolittorganisasjonen (ECCO), men det tilrådes ikke rutinemessig screening av EBV- og CMV-serologi før oppstart av behandling (21).

I en systematisk oversikt fra 2013 (19) ble halvparten ( 19 av 37 tilfeller) av hemofagocytisk lymfohistiocytose-episodene ved inflammatorisk tarmsykdom utløst av primærinfeksjon av Epstein-Barr-virus eller cytomelgalovirus. Det kan derfor være hensiktsmessig å avstå fra tiopurinbehandling hos pasienter med inflammatorisk tarmsykdom som er EBV- eller CMV-naive.
Med denne kasuistikken ønsker vi å minne om viktigheten av en sjelden, men potensielt livstruende tilstand, som kan forekomme hos pasienter med inflammatorisk tarmsykdom som mottar immunsupprimerende behandling, og da spesielt tiopuriner. Kombinasjonen av feber, pancytopeni og meget høy ferritin $(>10000 \mu \mathrm{g} / \mathrm{l})$ hos tiopurinbehandlede pasienter bør henlede mistanken mot hemofagocytisk lymfohistiocytose. Tidlig diagnostikk er avgjørende grunnet tilstandens høye mortalitet.

Pasienten har gitt samtykke til at artikkelen blir publisert.

Vi takker Ole Gunnar Aasprong, overlege ved Patologisk avdeling, Stavanger universitetssykehus, for hans hjelp til å innhente bilder av pasientens beinmargsaspirat.

\section{Jens Vikse (f. 1989)}

er medisinstudent ved Jagiellonian University i Krakow, Polen

Forfatter har fylt ut ICMJE-skjemaet og oppgir ingen interessekonflikter.

\section{Daniel Limi Cacic (f. 1987)}

er lege i spesialisering.

Forfatter har fylt ut ICMJE-skjemaet og oppgir ingen interessekonflikter.

\section{Arne Carlsen (f. 1977)}

er konstituert overlege. Forfatter har fylt ut ICMJE-skjemaet og oppgir ingen interessekonflikter.

\section{Trond Johan Cooper (f. 1982)}

er lege i spesialisering.

Forfatter har fylt ut ICMJE-skjemaet og oppgir ingen interessekonflikter.

\section{Tore Grimstad (f. 1968)}

er spesialist i indremedisin og fordøyelsessykdommer, overlege og postdoktor.

Forfatter har fylt ut ICMJE-skjemaet og oppgir følgende interessekonflikter: Han har mottatt forskningsstøtte fra AbbVie, Tillotts Pharma og Ferring Pharmaceuticals.

\section{Litteratur}

1. Bernstein CN, Blanchard JF, Houston DS et al. The incidence of deep venous thrombosis and pulmonary embolism among patients with inflammatory bowel disease: a population-based cohort study. Thromb Haemost 2001; 85: 430-4.

2. Moum B, Vatn MH, Ekbom A et al. Incidence of ulcerative colitis and indeterminate colitis in four counties of southeastern Norway, 1990-93. A prospective population-based study. Scand J Gastroenterol 1996; 31: 362-6.

3. Deltenre P. Berson A, Marcellin P et al. Mesala zine (5-aminosalicylic acid) induced chronic hepatitis. Gut 1999; 44: 886-8. 
4. Danese S, Fiocchi C. Ulcerative colitis. N Engl J Med 2011; 365: 1713-25

5. Konidari A, Matary WE. Use of thiopurines in inflammatory bowel disease: Safety issues. World J Gastrointest Pharmacol Ther 2014; 5: 63-76.

6. Costantino G. Furfaro F, Belvedere A et al. Thiopurine treatment in inflammatory bowel disease: response predictors, safety, and withdrawal in follow-up. J Crohn's Colitis 2012; 6: 588-96.

7. Siegel CA. Risk of lymphoma in inflammatory bowel disease. Gastroenterol Hepatol (N Y) 2009; 5: 784-90.

8. Maurier F, Petitpain N, Guichard JF et al. Olanzapine and pancytopenia with severe folate deficiency. Eur J Clin Pharmacol 2010; 66: 531-3.

9. Lui SY, Tso S, Lam M et al. Possible olanzapineinduced hepatotoxicity in a young Chinese patient. Hong Kong Med J 2009; 15: 394-6.

10. Skram MK, Bjering S, Hermansen NO et al. En 15 måneder gammel jente med feber og pancytopeni. Tidsskr Nor Legeforen 2011; 131: 2482-6.

11. Allen CE, Yu X, Kozinetz CA et al. Highly elevated ferritin levels and the diagnosis of hemophagocytic lymphohistiocytosis. Pediatr Blood Cancer 2008: 50: 1227-35.

12. Schram AM, Campigotto F, Mullally A et al. Marked hyperferritinemia does not predict for HLH in the adult population. Blood 2015; 125: 1548-52.

13. Kleynberg RL, Schiller GJ. Secondary hemophagocytic lymphohistiocytosis in adults: an update on diagnosis and therapy. Clin Adv Hematol Oncol 2012; 10: 726-32

14. Filipovich A, McClain K, Grom A. Histiocytic disorders: recent insights into pathophysiology and practical guidelines. Biol Blood Marrow Transplant 2010; 16 (suppl): S82-9.

15. Freeman HR, Ramanan AV. Review of haemophagocytic lymphohistiocytosis. Arch Dis Child 2011: 96: 688-93.

16. Beaugerie L, Brousse N, Bouvier AM et al. Lymphoproliferative disorders in patients receiving thiopurines for inflammatory bowel disease: a prospective observational cohort study. Lancet 2009; 374: 1617-25

17. van Langenberg DR, Morrison G, Foley A et al. Cytomegalovirus disease, haemophagocytic syndrome, immunosuppression in patients with IBD: a cocktail best avoided, not stirred'. J Crohn's Colitis 2011: 5: 469-72.

18. Virdis F, Tacci S, Messina F et al. Hemophagocytic lymphohistiocytosis caused by primary EpsteinBarr virus in patient with Crohn's disease. World J Gastrointest Surg 2013: 5: 306-8.

19. Fries W, Cottone M, Cascio A. Systematic review: macrophage activation syndrome in inflammatory bowel disease. Aliment Pharmacol Ther 2013; 37: $1033-45$.

20. James DG, Stone CD, Wang HL et al. Reactive hemophagocytic syndrome complicating the treatment of inflammatory bowel disease. Inflamm Bowel Dis 2006; 12: 573-80.

21. Rahier JF, Magro F, Abreu C et al. Second European evidence-based consensus on the prevention diagnosis and management of opportunistic infections in inflammatory bowel disease. J Crohn's Colitis 2014; 8: 443-68.

22. Jordan MB, Allen CE, Weitzman $\mathrm{S}$ et al. How I treat hemophagocytic lymphohistiocytosis. Blood 2011. 118: $4041-52$

Mottatt 16.9.2015, første revisjon innsendt 19.10. 2015, godkjent 29.3. 2016. Redaktør: Lars Frich. 